\title{
PENGEMBANGAN SISTEM INFORMASI PENDATAAN BEDAH RUMAH BERBASIS WEB PADA DINAS PERUMAHAN RAKYAT DAN KAWASAN PEMUKIMAN DI KABUPATEN SUMBAWA
}

\author{
Dendi Saputro ${ }^{1}$ I Made Widiarta ${ }^{2}$, M. Julkarnain ${ }^{3}$ \\ 1) Mahasiswa Informatika, Universitas Teknologi Sumbawa \\ 2) 3) Dosen Informatika, Universitas Teknologi Sumbawa \\ Email: dendisaputro888@gmail.com ${ }^{1)}$, made.widiarta@uts.ac.id²), m.julkarnain@uts.ac.id ${ }^{3)}$
}

\begin{abstract}
Abstrak
Dinas Perumahan Rakyat dan Kawasan Pemukiman (PRKP) Kabupaten Sumbawa memiliki peranan dalam penataan kota dibidang arsitektur dan memberikan pelayanan pada masyarakat dalam program pemerintah, meliputi pemerataan bantuan rumah tidak layak huni di wilayah Kabupaten Sumbawa untuk dilakukannya Bedah Rumah, proses pendataan warga masih dilakukan secara manual, sehingga petugas kesulitan dalam mendata warga dengan lokasi yang berbeda beda. Pengembangan Sistem Informasi Pendataan Bedah Rumah Berbasis Web pada Dinas Perumahan Rakyat dan Kawasan Pemukiman di Kabupaten Sumbawa, dirancang dalam memudahkan proses pendataan warga yang terintegrasi sistem dan memudahkan untuk melihat data warga yang akan menerima bantuan bedah rumah. Pengembangan sistem informasi ini menggunakan bahasa pemrograman Hypertex Preprocessor (PHP), pengelolahan database MySQL, dan metode pengembangan sistem yang digunakan metode waterfall. Hasil dari penelitian ini adalah terbangunnya sistem informasi pendataan warga yang akan menerima bantuan bedah rumah, laporan data warga yang terinput dan laporan data warga yang menerima bantuan.
\end{abstract}

Kata kunci : Sistem Informasi, web, Dinas PRKP, pendataan, bedah rumah.

\begin{abstract}
Housing and Settlement Area Office of Sumbawa Regency has a role in the architecture of urban layout and provide community service in government programs, including unlivable house renovation. The data recording is done manual basis, it generates difficulties to custodian when recording data for different location. Development of information system for unlivable housing assistance distribution e.g. unlivable house renovation on web basis in The Agency of Citizens Residential and Settlement Areas (PRKP) in Sumbawa Regency is designed to facilitate and integrated citizen recording system and to review the citizen that will receive the assistance from unlivable house renovation. This application is developed using Hypertext Preprocessor language program (PHP), MySQL database and the system development uses Waterfall method. The result of research is the citizens recording data who will receive an assistance from unlivable house renovation program, all citizens data and report of citizens that receive the assistance.
\end{abstract}

Keywords : Information system, web, data collection, house renovation.

\section{PENDAHULUAN}

Dinas Perumahan Rakyat dan Kawasan Pemukiman (PRKP) di Kabupaten Sumbawa merupakan suatu instansi pemerintah yang menunjang penataan kota dibidang arsitektur bangunan. Instansi ini juga memberikan pelayanan pada masyarakat dalam meningkatkan pemerataan bantuan rumah tidak layak huni diwilayah Kabupaten Sumbawa untuk dilakukannya bedah rumah. Program bedah rumah tersebut merupakan suatu program pemerintah yang telah berjalan pada Dinas PRKP.

Untuk mewujudkan rumah yang memenuhi persyaratan yang layak untuk ditempati, bukan hal yang mudah. Upaya pemerintah kabupaten Sumbawa, dalam menjalankan program bantuan bedah rumah yang nantinya akan diberikan pada masyarakat yang tidak memiliki kelayakan dalam tempat tinggalnya. Oleh karena itu untuk mempermudah dalam proses pemberian bantuan bedah rumah tersebut dilakukan pendataan warga yang menginginkan program tersebut.

Dari hasil pengamatan yang diamati oleh peneliti, setiap proses yang berjalan pada instansi PRKP masih terbilang berjalan secara manual, informasi mengenai program bedah rumah tersebut tidak tersosialisasikan secara merata, serta sistem pendataan masyarakat yang tidak terkomputerisasi pada setiap prosesnya dan aplikasi pendataan sebelumnya yang masih kurang relevan dikarenakan sisstem tidak berjalan dengan fungsi fungsi semestinya. 
Berdasarkan permasalahan yang terjadi, yang pada halnya proses yang berjalan pada dinas PRKP masih berjalan secara manual, meskipun terdapat sistem informasi namun sistem tersebut belum bisa berjalan dengan semestinya, sehingga perlu dilakukannya suatu penelitian tentang "Pengembangan Sistem Informasi Pendataan Bedah Rumah Berbasis Web pada Dinas Perumahan Rakyat dan Kawasan Pemukiman di Kabupaten Sumbawa".

Tujuan dibentuknya Sistem Informasi Pendataan Bedah Rumah Berbasis Web agar dalam proses pendataan warga dapat digunakan sesuai dengan yang semestinya oleh pihak Dinas PRKP Kabupaten Sumbawa, yang meliputi pendataan data warga yang dapat disimpan dalam bentuk sistem informasi yang berjalan pada komputer, serta memilah data yang akan diputuskan untuk mendapatkan bantuan bedah rumah, sehingga sistem informasi ini dapat membantu pihak Dinas PRKP dalam proses pengolahan data tanpa harus menggunakan sistem yang manual dalam proses pengerjaannya.

\section{LANDASAN TEORI}

\section{Tinjauan Pustaka}

Ada beberapa penelitian yang mengkaji tentang sistem informasi pendukung yang berkaitan dengan bedah rumah dan rumah tidak layak. Salah stau diantaranya adalah Sistem Pendukung Keputusan Penerima Bantuan Bedah Rumah Menggunakan AHP TOPSIS [3].

Penulisan jurnal tersebut membahas tentang, kesejahteraan sosial masyarakat dengan dua data dasar yaitu PMKS (Penyandang Masalah Kesejahteraan Sosial) dan PSKS (Potensi Kesejahteraan Sosial), deangan adanya kedua jenis data ini menjadi acuan dalam proses perencanaan, pelaksanaan, dan pengawasan program penyelenggaraan kesejahteraan sosial yang dilakukan oleh pemerintah kepada warga disetiap tahunnya, yang nantinya akan diarahkan secara langsung pada Kepala Dinas Sosial Budaya dan Pariwisata di Kabupaten Tabalong. Peneliti membangun sebuah metode pendukung keputusan menggunakan AHP untuk perhitungan bobot setiap kriteria dan metode TOPSIS untuk perangkingan warga serta sistem ini dibangun dengan menggunakan bahasa pemrograman PHP dan DBMS (Database Management System) MySQL, dengan penggabungan dua metode tersebut diharapkan penilaian akan lebih akurat, karena berdasarkan pada nilai criteria dan bobot yang sebelumnya diuji konsisten tidaknya terlebih dahulu.

Penelitian lain yang berkaitan adalah Pengembangan Sistem Informasi Pendataan Penduduk Tingkat Desa [6].
Dalam tulisan ini dibahas tentang sistem informasi pada tingkat desa biasanya masih menggunakan sistem yang manual. Hal ini menimbulkan beberapa kendala yang cukup merepotkan, terutama data yang tidak valid dan masalah kecocokan data, sehingga dibuat sistem informasi kependudukan, diharapkan sistem informasi pendataan penduduk ini dapat membantu instansi pemerintah dalam melakukan pendataan penduduk dalam lingkup sebuah desa.

Penelitian ketiga yang dijadikan sumber referensi yaitu Sistem Pendukung Keputusan untuk Penentuan Rumah tidak Layak Huni di Cangkring Rembang Kecamatan Karanganyar Demak [4]. Penulisan jurnal tersebut membahas tentang, kebutuhan rumah layak huni yang bersih, teratur dengan sarana dan prasarana infrastruktur yang memadai menjadi hak setiap warga.

Negara dalam hal ini pemerintah telah jelas mengaturnya didalam Undang Undang tersebut, spirit masyarakat untuk membangun desanya sendiri yang lebih baik tidak menjadi hal yang mustahil untuk diwujudkan, terlebih transfer dana dari pusat kedaerah dan desa lebih banyak dibandingkan kegiatan untuk lembaga, akan tetapi kenyataan fakta yang dilapangan, banyak warga khususnya desa-desa masih belum memiliki tempat tinggal yang dapat dikatakan layak huni. Pada penelitian ini penulis berusaha membantu membangun aplikasi sistem pendukung yang akan dijadikan sebagai objek didalam penentuan pemberian bantuan Pemugaran Rumah Tidak Layak Huni (RLTH) didesa Cangkring Rembang dalam upaya mewujudkan pemukiman desa yang layak huni yang menjadi hak setiap warganya.

Tulisan-tulisan di atas menjadi suatu dasar referensi peneliti dalam mengembangkan Sistem Informasi Pendataan Bedah Rumah pada Dinas PRKP di Kabupaten Sumbawa.

\section{Dasar Teori}

\section{Data}

Data merupakan suatu hasil pengukuran atau pengamatan berdasarkan kenyataan, baik berupa file, karakter, tulisan, gambar, ataupun fakta yang dapat diolah menjadi informasi [15],[17].

\section{Bedah Rumah}

Bedah rumah merupakan salah satu bantuan untuk menanggulangi kemiskinan difasilitasi oleh pemerintah, bantuan bedah rumah ataupun rehabilitasi rumah tidak layak huni (RTLH) merupakan bantuan social yang diberikan oleh pemerintah kabupaten Sumbawa kepada masyarakat berpenghasilan rendah (MBR) yang memiliki rumah btidak layak huni.sejak tahun 2008 s/d 2017 telah ditangani 1907 unit dengan besaran bantuan Rp.5.000.000 s/d 6.000.000 per unit.untuk pelaksanaan dengan alokasi 386 unit berupa 
bantuan sosial perumahan melalui BPKAD kabupaten Sumbawa. pelaksana teknis program 2008 s/d2017 dilaksanakan oleh badan pembe rdayaan masyarakat dan pemerintahan desa (BPMPD) sedangkan untuk tahun 2017 dan 2018 dilaksanakan oleh dinas perumahan rakyat dan kawasan permukiman (PRKP) Kabupaten Sumbawa [8].

Menurut UU No.1/2011 Pasal 18, Pemerintah Kab/Kota wajib Menyusun dan menyediakan basis data PKP pada Tingkat Kabupaten/Kota dan Pasal 98 yang berbunyi bahwa Penetapan lokasi perumahan kumuh dan permukiman kumuh wajib didahului proses pendataan yang dilakukan oleh pemerintah daerah dengan melibatkan peran masyarakat [9].

\section{METODOLOGI PENELITIAN}

\section{Metode Penelitian}

Jenis penelitian yang digunakan adalah penelitian kualitatif, yaitu metode yang dapat memecahkan masalah yang diselidiki dengan menggambarkan keadaan subjek atau objek yang diteliti pada saat sekarang berdasarkan fakta-fakta yang ada.

Tahap - tahap yang dilakukan metode ini untuk membangun data informasi pada bagan alur sebagai berikut:

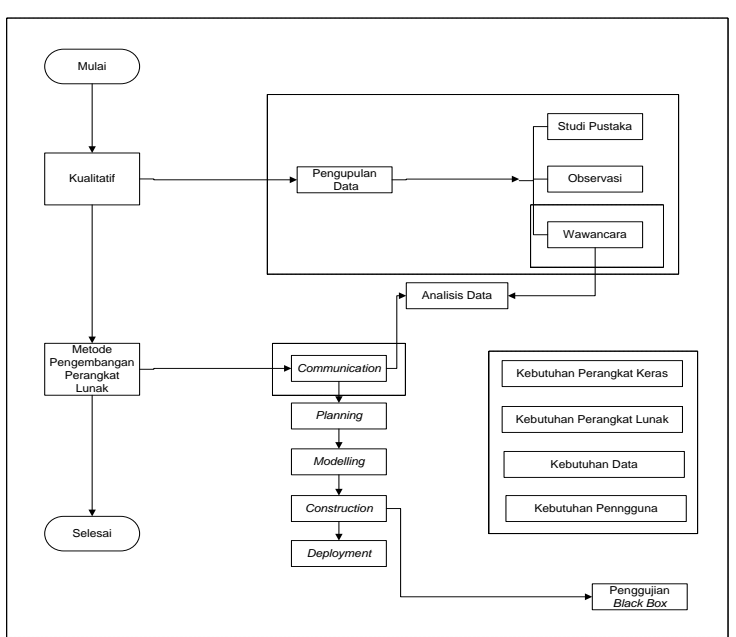

Gambar 1. Alur Penelitian

Metode penelitian yang digunakan dalam membangun sistem ini meliputi:

\section{Metode Pengumpulan Data}

Pengumpulan data dilakukan dengan studi pustaka dan wawancara. Metode tersebut adalah sebagai berikut:

\section{Studi Pustaka}

Studi kepustakaan merupakan langkah yang penting dimana setelah seorang peneliti menetapkan topik penelitian, langkah selanjutnya adalah melakukan kajian yang berkaitan dengan teori yang berkaitan dengan topik penelitian. Sumber-sumber kepustakaan dapat diperoleh dari: buku, jurnal, majalah, hasil-hasil penelitian, dan sumber-sumber lainnya yang sesuai seperti internet, koran dan lain-lain, Data yang diperoleh meliputi:

i. Buku-buku referensi serta ebook yang berhubungan dengan penelitian.

ii. Jurnal dan skripsi yang berhubungan dengan penelitian.

iii. Artikel yang didapat dan di unduh dari internet.

\section{Wawancara}

Wawancara dilakukan dengan mengadakan tanya jawab secara langsung kepada karyawan instansi Dinas PRPK Kabupaten Sumbawa selaku narasumber sehingga bisa mendapatkan data-data yang diperlukan untuk Pengembangan Sistem Informasi Pendataan Bedah Rumah Berbasis Web Pada Dinas PRKP Kabupaten Sumbawa.

\section{A. Metode Pengembangan Perangkat Lunak}

Metode pengembangan sistem merupakan metode prosedur, konsep-konsep pekerjaan, aturan akan digunakan untuk mengembangkan suatu sistem informasi Pengembangan sistem didefinisikan sebagai sistem informasi berbasis komputer untuk menyelesaikan persoalan organisasi atau memanfaatkan kesempatan model air terjun (waterfall). Dalam buku [7] dijelaskan bahwa model waterfall adalah model klasik yang bersifat sistematis, berurutan dalam membangun software. Nama model ini sebenarnya adalah "Linear Sequential Model" yang sering disebut juga dengan "Classic life cycle" atau metode waterfall. Model ini termasuk ke dalam model generic pada rekayasa perangkat lunak, model yang paling banyak dipakai dalam SoftwareEngineering (SE). Model ini melakukan pendekatan secara sistematis dan berurutan. Disebut dengan waterfall karena tahap demi tahap yang dilalui harus menunggu selesainya tahap sebelumnya dan berjalan berurutan.

Berikut tahapan metode waterfall yang dilakukan pada pengembangan perangkat lunak:

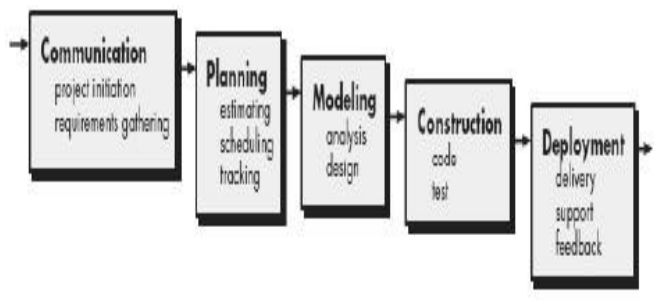

Gambar 2. Waterfall Model 
Dalam pengembangan Sistem Informasi Pendaftaran Pendataan Bedah Rumah pada Dinas Peumahan Rakyat dan Kawasan Pemukiman di kab Sumbawa, penulis menggunkana metode waterfall dengan 5 langkah yaitu sebagai berikut:

\section{Communication}

Tahapan pertama dari metode pengembangan perangkat lunak waterfall yang penulis gunakan yaitu communication. Dari hasil wawancara dan observasi sebagai teknik pengumpulan data yang dilakukan di Instansi terkait, dengan hal itulah peneliti mengumpulkan informasi tentang kebutuhan pengguna atau pendaftar yaitu model sistem dengan pendekatan input, proses dan output yang dijelaskan sebagai berikut:

i. Hasil Wawancara

Dari wawancara yang dilakukan, diperoleh informasi:

a) Dinas PRKP Kabupaten Sumbawa membutuhkan sistem pendataan yang lebih mudah yang nantinya akan langsung tersimpan pada suatu database. seperti, pendataan warga, pendataan Kartu Keluarga dan pendataan penerima bantuan.

b) Database yang dibutuhkan oleh instansi tersebut harus dapat menyimpan data dengan baik agar sewaktu-waktu saat data dibutuhkan petugas / admin dapat dengan mudah untuk mengakses.

c) Dinas PRKP di kab Sumbawa membutuhkan sistem yang dapat mempermudah dalam pembuatan laporan, dimana data yang telah tersimpan pada database bisa langsung di cetak dalam bentuk laporan.

ii. Hasil Observasi

Adapun hasil observasi penulis saat terjun langsung dalam menijau setiap proses sistem yang berjalan sebelumnya, masih terbilang manual bai dari pengumpulan setiap data warga dalam bentuk hardware/ berkas informasi warga dalam bentuk tumpukan kertas yang lama kelamaan terjadi penumpukkan berkas dan rumit memilahnya dalam setiap data, meskipun ada beberapa data yang di input dalam komputer utuk laporan hasilnya.

\section{Planning}

Tahapan kedua yaitu planning, dimana penulis telah membuat jadwal pengerjaan project selama 4 (empat) bulan terhitung dari bulan maret sampai dengan bulan Juni 2019.

\section{Modelling}

Tahap ketiga dari metode ini adalah modeling, dimana dalam tahap ini penulis melakukan tiga perancangan yaitu, rancangan sistem usulan, rancangan struktur database dan rancangan tampilan program.

\section{Construction (Konstruksi)}

Tahapan keempat dalam pembuatan sistem informasi pendataan bedah rumah berbasis web yaitu konstruksi yang meliputi proses pengkodingan dan uji coba terhadap sistem. Namun pada saat pengujian program belum selesai maka proses akan kembali menganalisa kebutuhan data sistem yang akan dibangun untuk memastikan bahwa sistem yang dibangun sudah sesuai dengan kebutuhan dari sistem.

\section{Deployment}

Tahapan ini merupakan final dalam pembuatan sistem informasi pendataan bedah rumah berbasis web. Sistem yang telah dibuat harus dilakukan pemeliharaan secara berkala. Dan pada tahapan ini sistem siap diimplementasikan.

\section{HASIL DAN PEMBAHASAN Analisa Sistem}

Perbandingan sistem yang berjalan pada instansi terkait, dengan sistem yang akan dibangun oleh penulis diuraikan pada Tabel 1 di bawah ini.

Tabel 1. Perbandingan Sistem yang Berjalan dan Sistem yang Dibangun

\begin{tabular}{|c|c|c|}
\hline No & $\begin{array}{c}\text { Sistem yang } \\
\text { berjalan }\end{array}$ & $\begin{array}{c}\text { Sistem yang } \\
\text { dibangun }\end{array}$ \\
\hline 1 & $\begin{array}{l}\text { Pendataan } r \\
\text { warga dan kete- } \\
\text { rangan kartu } \\
\text { keluarga warga } \\
\text { yang masih ber- } \\
\text { sifat manual } \\
\text { seperti identitas } \\
\text { warga, data kartu } \\
\text { keluarga, data } \\
\text { penerima bantu- } \\
\text { an, dan data gam- } \\
\text { bar rumah warga }\end{array}$ & $\begin{array}{l}\text { Pendataan } \\
\text { menggunakan } \\
\text { teknologi komputer } \\
\text { dan langsung akan } \\
\text { tersimpan di suatu } \\
\text { basis data berdasarkan } \\
\text { jenis datanya. }\end{array}$ \\
\hline 2 & $\begin{array}{lr}\text { Dokumen masih } \\
\text { berbentuk buku } \\
\text { atau berkas yang } \\
\text { menumpuk di } \\
\text { dalam lemari. }\end{array}$ & $\begin{array}{l}\text { Penyimpanan data } \\
\text { akan tersimpan di } \\
\text { suatu penyimpanan } \\
\text { basis data, yang akan } \\
\text { mempermudah admin } \\
\text { saat data dibutuhkan. }\end{array}$ \\
\hline 3. & $\begin{array}{lr}\text { Pencarian } & \text { data } \\
\text { yang } & \text { bersifat } \\
\text { manual } & \text { dan } \\
\text { memakan } & \text { waktu } \\
\text { yang cukup lama } \\
\text { dalam rases } \\
\text { pencarian. }\end{array}$ & $\begin{array}{l}\text { Pencarian data warga } \\
\text {,data kartu keluarga, } \\
\text { dan penerima bantu-an } \\
\text { bedah rumah, tidak } \\
\text { memerlukan waktu } \\
\text { lama karena user } \\
\text { hanya perlu me- } \\
\text { masukkan kata kunci } \\
\text { seperti nama ataupun } \\
\text { NIK warga akan } \\
\text { langsung teridenti- } \\
\text { fikasi berdasarkan clu } \\
\text { kuncinya. }\end{array}$ \\
\hline
\end{tabular}




\begin{tabular}{|c|c|c|}
\hline 4. & $\begin{array}{l}\text { Laporan data yang } \\
\text { sering tercampur } \\
\text { dengan data } \\
\text { lainnya sehinga } \\
\text { membuat } \\
\text { pemilahan data } \\
\text { yang sangat } \\
\text { memakan waktu } \\
\text { dalam pemilahan } \\
\text { laporan data }\end{array}$ & $\begin{array}{lr}\text { Data yang } & \text { tersimpan } \\
\text { dibasis } & \text { data } \\
\text { berdasakan } & \text { field } \\
\text { ataupun jenis } & \text { datanya } \\
\text { dapat dicetak } & \text { kembali } \\
\text { dalam } & \text { bentuk } \\
\text { hardware } & \text { sesuai } \\
\text { keininan } & \text { admin } \\
\text { ataupun data } & \text { yang } \\
\text { dibutuhkan oleh pihak } \\
\text { instansi } & \text { sebagai } \\
\text { laporan hasil. }\end{array}$ \\
\hline
\end{tabular}

\section{Rancangan Sistem Usulan}

Adapun alur kerja sistem yang sedang berjalan dapat dijabarkan sebagai berikut:

\section{Alur kerja sistem yang berjalan}

Tahapan yang dibutuhkan dalam membanngun sebuah program yaitu menganalisis sistem yang sedang berjalan. Analisis terhadap sistem yang berjalan bertujuan untuk mengetahui masalah yang ada untuk dijadikannya suatu landasan dalam usulan perancangan sistem yang akan dibuat.

Berdasarkan hasil Interview dan observasi, yang dilakukan penulis dengan Dinas Perumahan Rakyat Dan Kawasan Pemukiman dikabupaten Sumbawa, diketahui sistem yang berjalan saat ini masih dilakukan secara manual, dan belum terintegrasi dengan sistem informasi.

Adapun proses alur kerja sistem Pendataan Bedah Rumah yang sedang berjalan saat ini digambarkan dalam flowmap berikut.

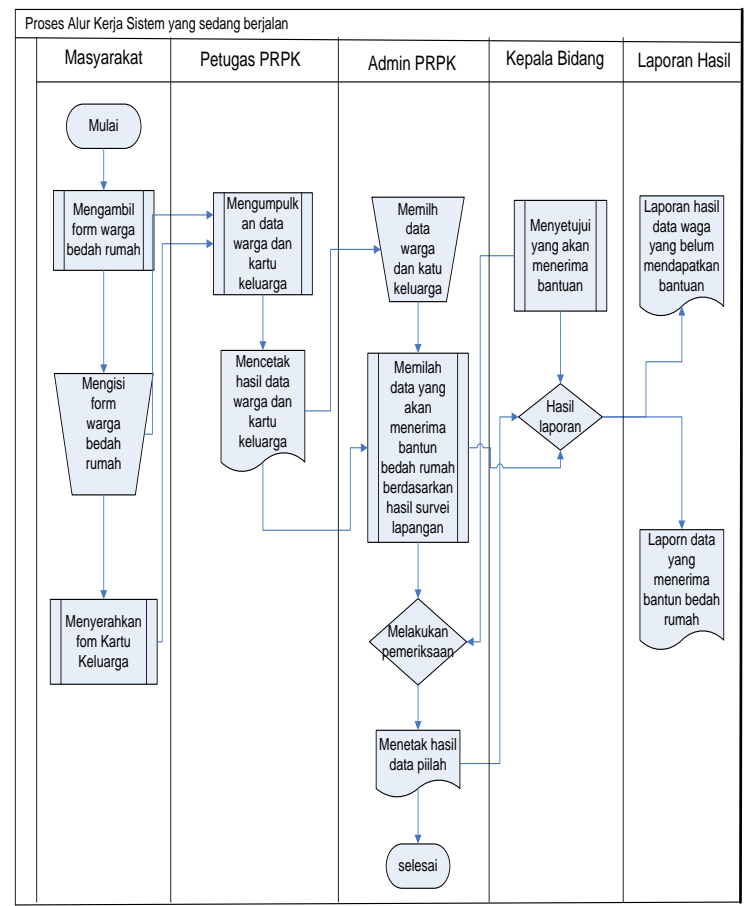

Gambar 3. Flowmap yang Sedang Berjalan
Dalam proses yang sedang berjalan diatas menjelaskan 4 bagian proses yaitu Masyarakat, Petugas PRKP, Kepala Bidang dan Laporan hasil, yang nantinya masyaraat yangn ingin mendapatkan bantuan bedah rumah harus menngambil form identitas warga terlebih dahulu dan mengisi form identitas warga dan menyerahkan kembali form data tersebut beserta foto copy kartu keluarga ke petugas PRPK , Selanjutnya petugas PRKP menyimpan arsip identitas warga dan arsip kartu keluarga berdasaarkan kartu keluarga yang dimilikinya dan diserahkan kepada bagian admin PRKP yang akan menentukan warga yang berhak mendapatkan bantuan bedah rumah berdasarkan hasil survei lapangan terhadap lokasi warga kemudian data yang berhak mendapatkan bantuan dipilah oleh admin PRKP serta dengan persetujuan kepala bidang dan berkas warga yang belum mendapatkan bantuan dan yang akan mendapatkan bantun di arsipkan sebagai laporan hasil.

\section{Alur Rancangan Sistem Usulan}

Hasil rancangan sisitem usulan pada Sistem Pendataan Bedah Rumah dapat gambarkan sebagai berikut

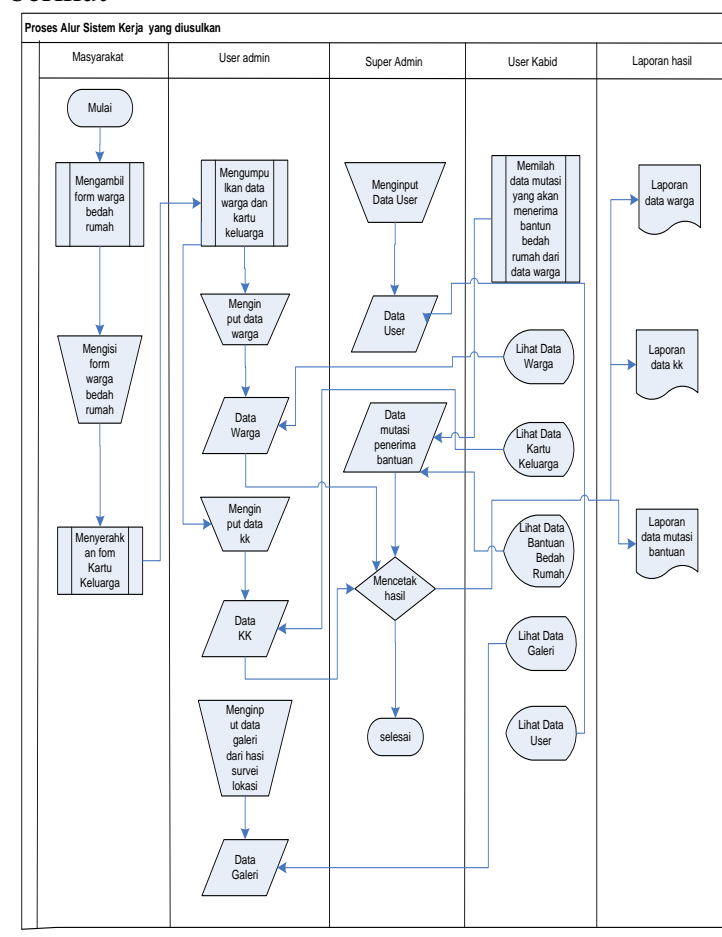

Gambar 4. Flowmap Rancangan Sistem Usulan

Pada Gambar 4 flowmap rancangaan sistem usulan diatas menelaskan ada 5 bagian proses yaitu masyarakat, user admin, super admin, user kabid dan laporan hasil, yang mana pada proses dibagian masyarakat masih menggunakan alur sistm kerja yang lama namun pada setiap pengimputan data menggunakann sistem yang terintegrasi dan peneliti memfokuskan sistem pada bagian internal ataupun proses penginputan data pada user admin, 
super admin dan user kabid pada petugas Dinas PRKP kabupaten Sumbawa.

Super admin berhak membuat user baru serta memberikan username dan password dan memilliki hak akses penuh pada sistem informasii tersebut, Proses yang akan berjalan nantinya user admin akan menginput data waga dan data kartu keluarga kedalam sistem kemudian User Kabid akan memillah ataupun memutasi data warga ke data yang akan menerima bantuan ataupu menyetujui bahwa data warga tersebut yang berhak menerima bantuan bedah rumah, dan setiap data warga, data kartu keluarga dan data bantuan bedah rumah dapat dicetak yang nantinya diarsipkan sebagai laporan pada Dinas Perumahan Rakyat dan Kawasan Pemukiman.

\section{A. Data Flow Diagram}

Data Flow Diagram (DFD) disebut juga dengan Diagram Arus Data (DAD). DFD adalah suatu diagram yang menggunakan notasi-notasi untuk menggambarkan arus dari data sistem, yang penggunaannya sangat membantu untuk memahami sistem secara logika, tersruktur dan jelas. Adapun DFD dapat dilihat pada gambar berikut:

\section{Gambar Konteks Sistem}

Gambar konteks merupakan gambaran umum dari organisasi sistem yang akan dibangun. Gambar konteks juga merupakan gambaran aliran data yang ada pada sistem secara keseluruhan dan bertujuan untuk mengenal pasti sistem yang akan dibuat.

Gambar berikut menunjukan gambar konteks Sistem Pendataan Bedah Rumah

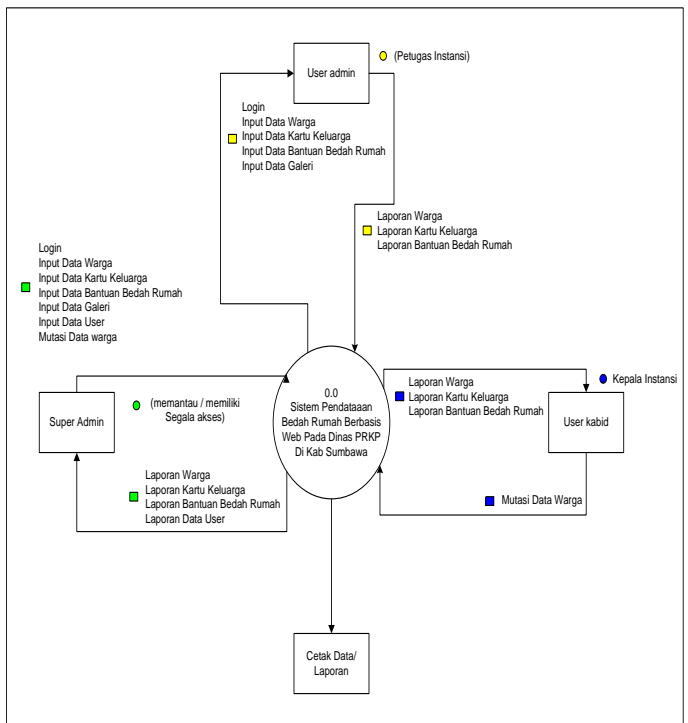

Gambar 5 Konteks Level 0.0 Sistem Pendataan Bedah Rumah

\section{Gambar aliran Data Level 0}

Berdasarkan Gambar 5, konteks diagram sistem pendataan bedah rumah terbagi dalam 7 aktifitas utama yaitu, proses login, proses input data warga, proses penginputan kartu keluarga, proses data yang termutasi dari data warga ke data bedah rumah, proses data galeri, proses input data user baru dan proses cetak data / laporan. Aktifitas secara keseluruhan beserta aliran datanya ditunjukan pada gam bar sebagai berikut:

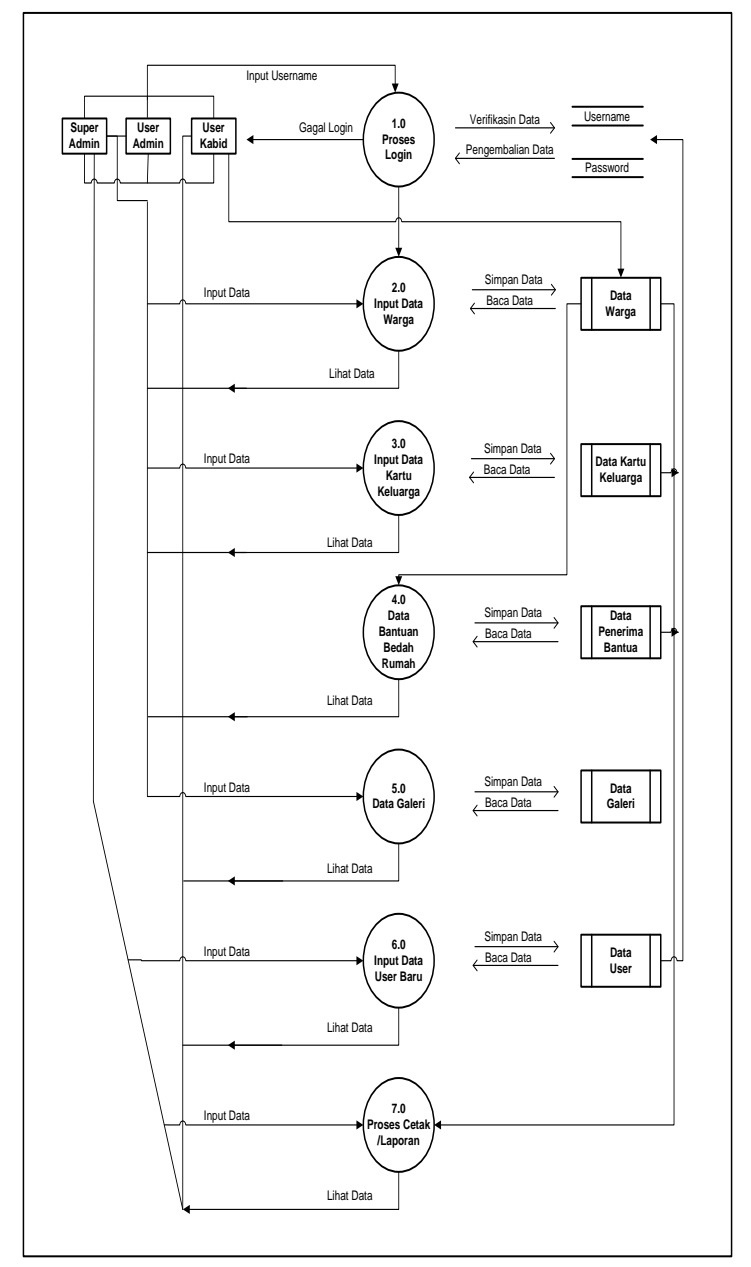

Gambar 6. Aliran Data Level 0.0 Sistem Pendataan Bedah Rumah

\section{B. ER Diagram}

ER Diagram merupakan suatu model untuk menjelaskan hubungan antar data dalam basis data berdasarkan objek-objek dasar data yang mempunyai hubungan antar relasi.ER Diagram untuk memodelkan struktur data dan hubungan antar data, untuk menggambarkannya digunakan beberapa notasi dan symbol. Perhatikan ER Diagram pada gambar berikut ini. 


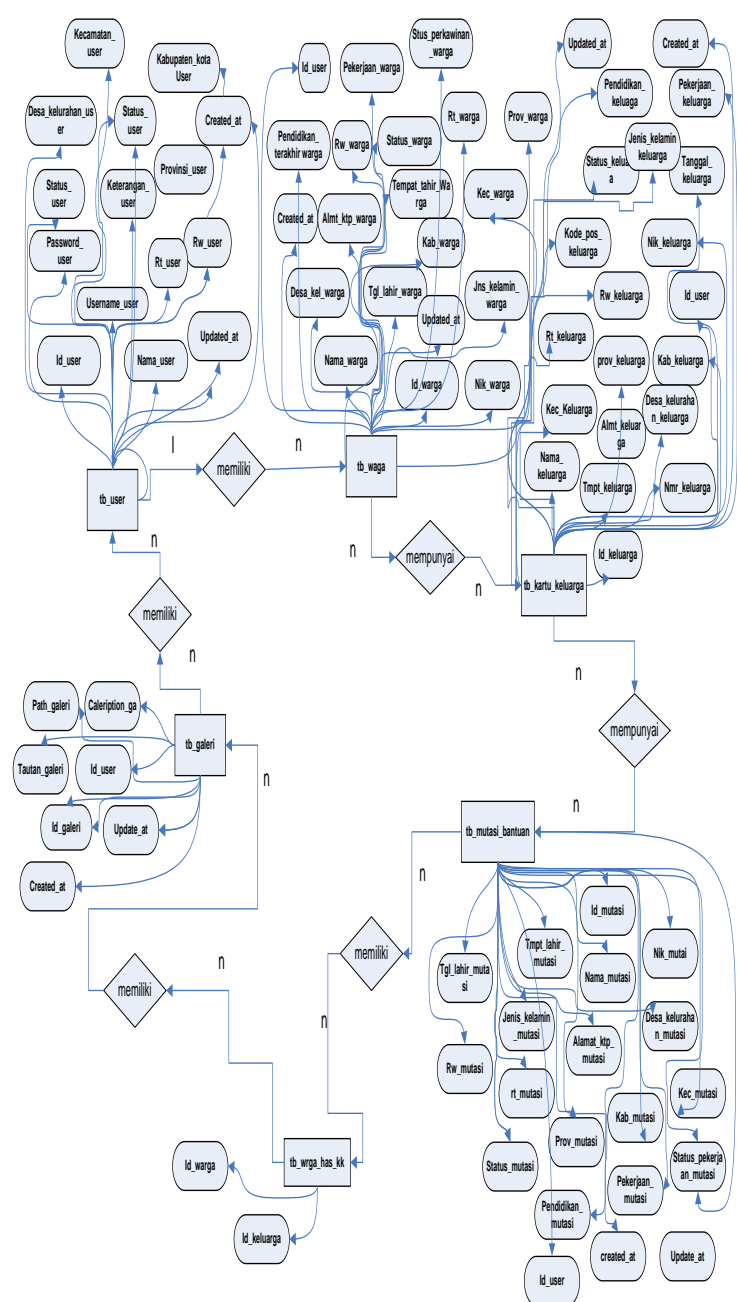

Gambar 7. ERD yang Diusulkan

\section{Rancangan Struktur Database}

Struktur database pada Pendataan Bantuan Rumah dibutuhkan beberapa tabel yaitu tb_user, tb_warga,tb_kartu_keluarga,tb_galeri,tb_mutasi_b antuan dan tabel tb_warga_has_kk. Tabel-tabel tersebut dapat digambarkan sebagai berikut:

\section{Relasi Antar Tabel}

Relasi antar tabel merupakan kumpulan tabeltabel yang terhubung melalui relasi untuk membentuk satu kesatuan database sehingga tabel tidak berdiri sendiri.

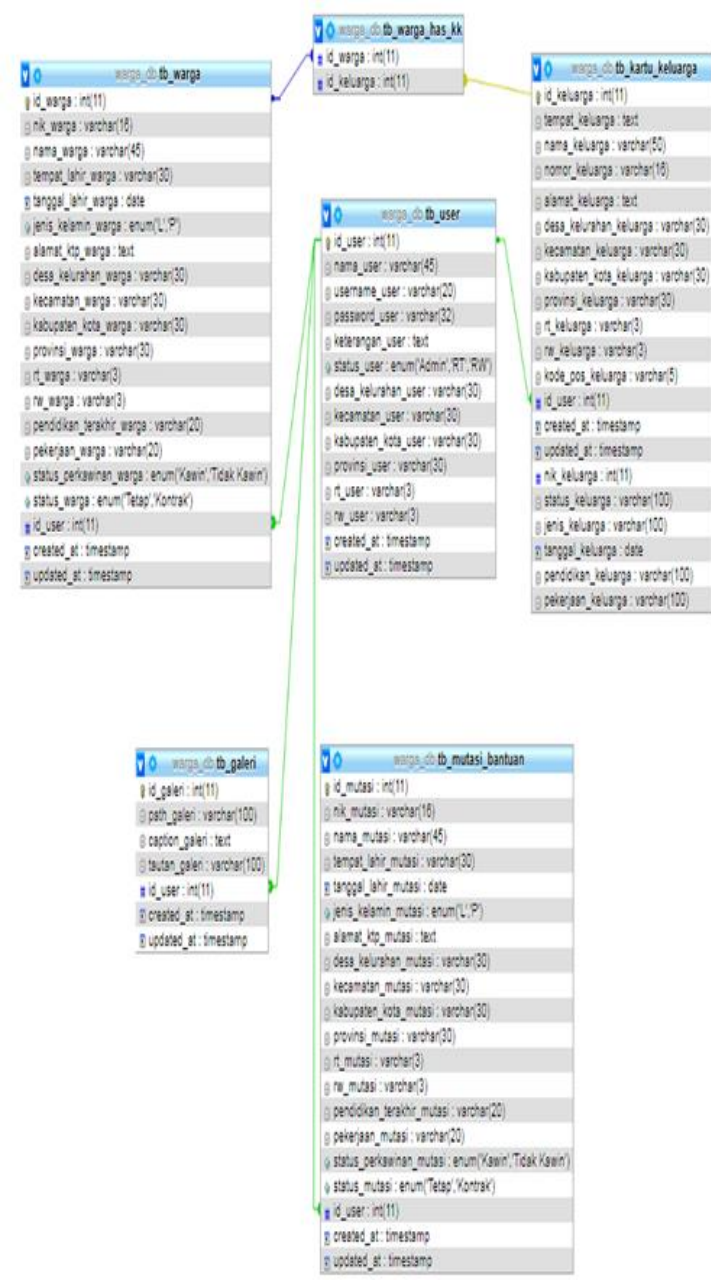

Gambar 8. Relasi Tabel dalam database warga_db

\section{Rancangan User Interface}

Rancangan user interface merupakan rancangan tampilan antarmuka dari sistem yang akan dibangun. Berikut merupakan rancangan user interface dari Sistem Informasi Pendaataa Bantuan Bedah Rumah dikabupaten Sumbawa.

\section{Tampilan Interface Data Warga}

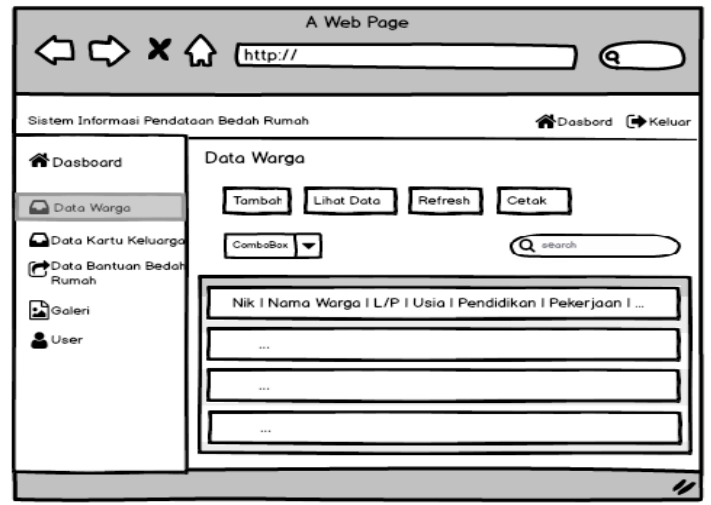

Gambar 9. Rancangan Interface Warga 
Dalam form ini dapat melihat hasil data warga yang telah ditambahkan. Kemudian di dalam form ini juga terdapat tampilan total dari warga yang telah ditambahkan, pencarian data warga berdasarkan nama, dan dapat mencetak data warga.

\section{Tampilan Interface Tambah Data Warga}

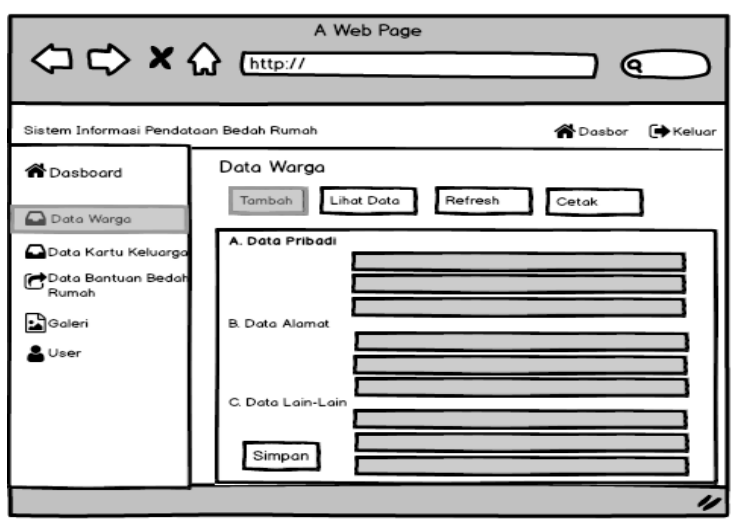

Gambar 10. Rancangan Interface Tambah Data Warga

Dalam form aksi Tambah Data Warga merupakan bagian penginputan data mengenai identitas warga dengan tiga bagian yang ada pada form yaitu data pribadi, data alamat dan data lain lain mengenai warga.

\section{Implementasi}

Berikut ini merupakan implementasi dari kode program pada Pengembangan Sistem Informasi Pendataan Bedah Rumah Berbasis Web pada Dinas Perumahan Rakyat dan Kawasan Pemukiman di Kabupaten Sumbawa.

Adapun implementasi dari pembuatan kode program tersebut adalah sebagai berikut:

\section{Implementasi pada Form Data Warga}

Adapun form data warga adalah sebagai berikut:

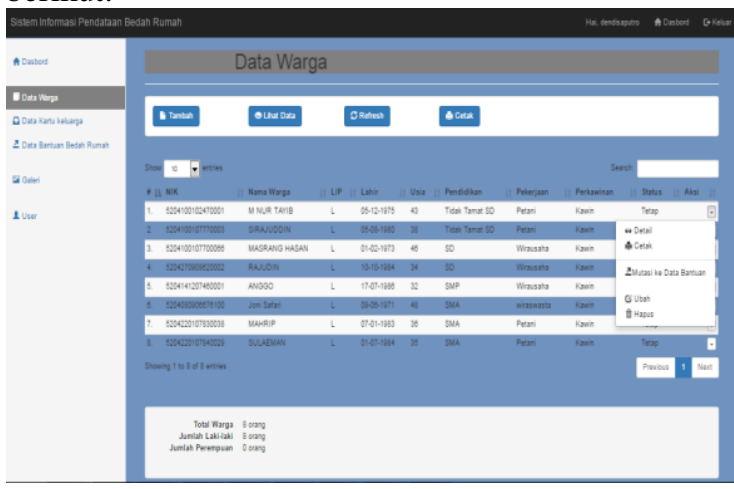

Gambar 11. Form Aksi Data Warga

Dalam form aksi terdapat detail untuk melihat keseluruhan dari data warga perorangan, cetak data warga secara perseorangan ubah data warga, update data warga, kemudian terintegrasi dengan data bantuan warga, kemudian terdapat hapus data warga.

\section{Implemtasi pada Form Tambah Data warga}

Adapun form tambah data warga dari aksi yang terdapat di dalam data warga adalah sebagai berikut:

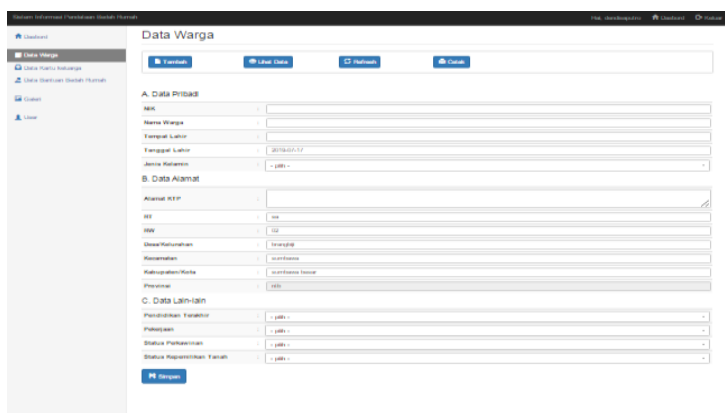

Gambar 12. Tambah Data Warga

Dalam form aksi Tambah Data Warga terdapat Data Pribadi untuk menginput Nomor Induk Kependudukan, nama warga, tempat Lahir, tanggal lahir dan jenis kelamin pada tambah data warga, setelah menginput data pribadi selanjutnya menginput data alamat yang di dalamnya terdapat Alamat sesuai Kartu Tanda Penduduk (KTP), Rt, Rw, Desa atau kelurahaan, Kabupaten atau Kota dan Provinsi. Setelah menginput data alamat selanjutnya menginput Data lain yang di dalamnya terdapat pendidikan terakhir, pekerjaan, status perkawinan dan status kepemilikan tanah yang dapat di pilih, setelah semua telah diinput maka dapat memilih untuk melakukan proses simpan data.

\section{Implementasi Form pada Hasil Cetak Detail}

Hasil cetak dari aksi yang terdapat di dalam data warga adalah sebagai berikut :

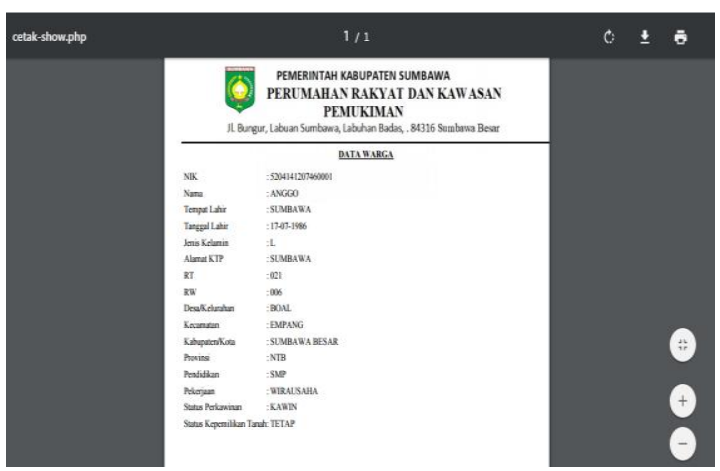

Gambar 13. Cetak Data Detail Warga

Setelah melakukan cetak data warga maka proses tersebut dapat berjalan dan laporan data warga dicetak ke dalam bentuk pdf serta dapat diprint atau disimpan. 


\section{Implementasi Form pada Hasil Cetak Keseluruhan}

Hasil cetak dari aksi yang terdapat di dalam data warga adalah sebagai berikut:

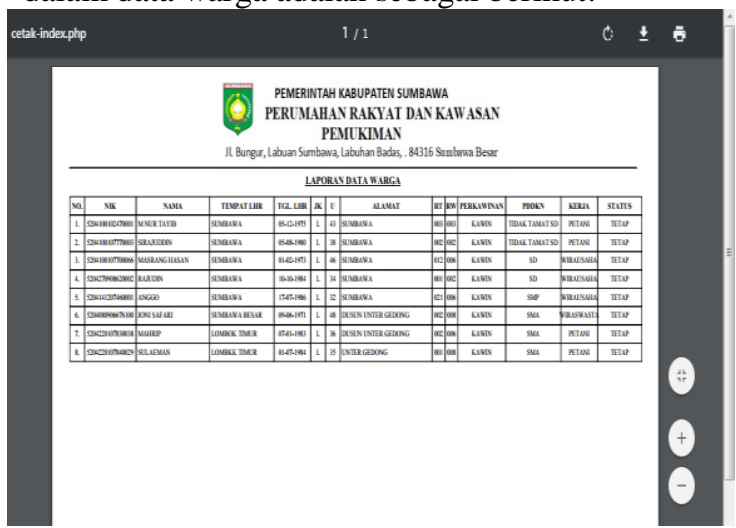

Gambar 14. Cetak Data Keseluruhan Warga

Setelah melakukan cetak data warga maka proses tersebut dapat berjalan dan laporan data warga dicetak ke dalam bentuk pdf serta dapat diprint atau disimpan.

\section{PENUTUP}

\section{Kesimpulan}

Pengembangan Sistem Informasi Pendataaan Bedah Rumah Berbasis Web Pada Dinas Perumahan Rakyat dan Kawasan Pemukiman Di Kabupaten Sumbawa menghasilkan suatu sistem yang berbasis web menggunakan baahasa pemrograman PHP dan MySQL sebagai database, metode waterfall sebagai metode peraangkaat lunak yang digunakan, serta menggunakan metode black box dalam pengujiannya, yang diharapkan dapat mempermudah dalam proses pendataan warga, pendataan kartu keluarga, dan pendataan warga yang mendapat bantuan bedah rumah, galeri mengenai keadaan rumah yang masih proses renovasi atau yang telah direnovasi dari proses inputan secara manual menjadi terkomputerisasi.

\section{Saran}

Adapun saran yang dapat disampaikan mengenai Pengembangan Sistem Informasi Pendataan Bedah Rumah Berbasis Web ini adalah diharapkan adanya pengembangan yang lebih lanjut dalam proses pembuatan form laporan perdesa atau per kecamatan yang terintegrasi pada sistem pendataan bedah rumah dan form data warga yang dapat terinput beserta data gambar rumah secara detailnya, agar membuat sistem lebih terperinci dari setiap aspek pendataannya.

\section{DAFTAR PUSTAKA}

[1] Abdillah, L.A. dkk. (2005). Perancangan Basis Data Sistem Informasi Penggajian.Tesis, Palembang: Universits Bina Darma.

[2] Jogianto, Hartono. (2005).Analisis Dan DesainSistemInformasi.Yogyakarta: Andi.

[3] Khoiruninisa, Sekar Sae. (2016). "Sistem Pendukung Keputusan Penerima Bantuan Bedah Rumah Menggunakan Metode AHP TOPSIS(StudiKasus: Ikatan Pekerja Sosial Masyarakat Kecamatan Mutiara Uya, Kabupaten Tabalong, Kalimantan Selatan)", dalam Seminar Nasional Departemen Ilmu Komputer/Informatika Universitas Diponegoro Semarang, 03 Agustus 2016. ISBN : 240-103-1014-10-40. Diakses 01 Maret 2019.

[4] Nurkhamid, Muhammad. (2017). "Sistem Pendukung Keputusan Untuk Penentuan Rumah Tidak Layak Huni di Cangkring Rembang(StudiKasus: Karanganyar Demak)”, dalam Seminar Nasional Teknik Informatika 2017 Universitas Muria Kudus Gondang Manis, 11 Februari 2017. ISBN : 978-602-1180-50-1. Diakses 03 Maret 2019.

[5] O’Brien, James A. \&Marakas, George M. (2009). Management Information Systems 9th Edition.New York: McGraw-Hill/ Irwin.

[6] Prastyo, Suparno Dedy. (2009). Pengembangan Sistem Informasi Penduduk Tingkat Desa(StudiKasus: Desa Ujungrusi, Kec. Adiwerna, Kab. Tegal), dalam Seminar Nasional Teknik Informatika 2009 Universitas Islam Agung Semarang, ISBN : 978-602-95235-0-8. Diakses 03 Maret 2019.

[7] Pressman, Roger S. (2015). Rekayasa Perangkat Lunak Pendekatan Praktisi. Andi. Yogyakarta.

[8] PUPR, JDIH Kementrian. (2015). "Peraturan Presiden (PERPRES) Nomor 15 Tahun 2015”, (diakses 06 Maret 2019).

[9] Republik Indonesia. (2011). Undang-Undang No. 1 Tahun 2011 Tentang Perumahan Dan Kawasan Permukiman. Lembaran Negara RI Tahun 2011, No. 61. Sekretariat Negara. Jakarta.

[10] Rizky, Soetam. (2011).Konsep Dasar Rekayasa Perangkat Lunak. Jakarta: PT. Prestasi Pustakaraya.

[11] Sekarwati, K.A., (2001). Pengertian Database. Study Kasus: Cassandra dan 
MongoDB, Prosiding pada Seminar Nasional dan Expo Teknik Elektro.

[12] Sutabri, Tata. (2012). KonsepSistemInformasi. Yogyakarta: Andi.

[13] Sutanta. (2011). Dalam Basis Data Dalam Tinjauan Konseptual.

[14] Sutanta, Edhy. (2004). Sistem Informasi Manajemen. Yogyakarta: Graha ilmu.

[15] Sutarman. (2012).Buku Pengantar Teknologi Informasi. Jakarta: Bumi Aksara.
[16] Sukamto, R. A, dan Shalahu6din, M. (2014). Rekayasa Perangkat Lunak Terstruktur dan Berorientsi Objek. Bandung: Informatika bandung.

[17] Wahyudi. (2012). Definisi data.S1 Sriwijaya: Politeknik Negeri Sriwijaya. 